\title{
Genetic Variability and Character Association Studies in Maize (Zea mays L.) Inbred Lines
}

\author{
V. Supraja ${ }^{1 *}$, H. C. Sowmya ${ }^{1}$, P. H. Kuchanur ${ }^{1}$, B. Arunkumar ${ }^{1}$ and B. Kisan ${ }^{2}$ \\ ${ }^{1}$ Department of Genetics and Plant Breeding, University of Agricultural Sciences, Raichur- \\ 584104, Karnataka, India \\ ${ }^{2}$ Department of Molecular Biology and Agricultural Biotechnology, University of Agricultural \\ Sciences, Raichur - 584 104, Karnataka, India \\ *Corresponding author
}

\section{A B S T R A C T}

Keywords

Genetic variability,

Heritability,

Genetic advance,

Character association, Maize

Article Info

Accepted:

07 September 2019

Available Online:

10 October 2019
The present investigation was conducted to evaluate the various parameters of genetic variability and nature of associations among traits affecting grain yield in 50 inbred lines of maize (Zea mays L.) at Command Area Development Authority Experimental Block, Agricultural Research Station, Bheemarayanagudi (Karnataka) during Rabi 2018. The analysis of variance revealed that highly significant differences exist among the inbred lines for all the characters except for anthesis silking interval. High heritability coupled with high genetic advance (\% of mean) was observed in number of grains per row, number of grains per cob, plant height, grain yield per plant, 1000 kernel weight and grain yield ( $\mathrm{kg} / \mathrm{ha}$ ), indicating the influence of additive gene action in controlling the traits. The important yield attributing traits viz., shelling percentage, number of grains per row and plant height showed positive association at both phenotypic and genotypic levels. At phenotypic level, the character number of grains per cob recorded highest positive direct effect on grain yield followed by shelling percentage, days to $50 \%$ anthesis and plant height. At genotypic level, the characters viz., days to $50 \%$ anthesis, number of grains per cob, shelling percentage exhibited high direct positive effect on grain yield.

\section{Introduction}

Maize (Zea mays L.) commonly known as corn is the third most important cereal crop worldwide after rice and wheat. It plays an important role in the world economy. It is one of the most widely distributed crops of the world owing to its expansive adaptability under diverse agro-climatic conditions and is also a valuable ingredient in industrial products that affect a large proportion of the world population. Inbred lines are important as they represent a fundamental resource for studies in genetics and breeding which are 
used extensively in hybrid corn production. Grain yield is the most important and complex trait i.e. interdependent on various other yield attributing traits.

Knowledge of genetic variation and relationships between lines is a prerequisite for any improvement in traits of economic importance as it helps to understand the magnitude of genetic variability which provides the basis for effective selection. Knowledge of heritability coupled with genetic advance is most useful in predicting the scope for genetic improvement through selection as heritability alone provide the basis for selection on phenotypic performance that doesn't indicate the amount of genetic improvement resulting from the selection of individual genotypes (Ghosh et al., 2014). Studies of correlation and path coefficient analysis would be very important to design appropriate breeding strategies for improvement in yield through selection to have better understanding of the relationship among yield related traits (Dewey and Lu, 1959).

\section{Materials and Methods}

The 50 inbred lines were raised in a Randomized Block Design (RBD) in three rows of $4.0 \mathrm{~m}$ length at a spacing of $60 \mathrm{~cm}$ between rows and $20 \mathrm{~cm}$ within row spacing with three replications. The evaluation of maize inbred lines was carried out at College of Agriculture, Bheemarayanagudi (Karnataka) situated at $16^{\circ} 44^{\prime} \mathrm{N}$ latitude and $76^{\circ} 47^{\prime}$ E longitude with an altitude of $458 \mathrm{~m}$ above mean sea level. Data was recorded on five randomly selected plants from each replication for traits like plant height $(\mathrm{cm})$, number of leaves, number of internodes, cob length $(\mathrm{cm})$, cob girth $(\mathrm{cm})$, number of grain rows per cob, number of grains per row, number of grains per cob, 1000 kernel weight (g) and grain yield per plant (g) and the mean of five plants was computed. Whereas, grain yield was recorded on plot basis and expressed in $\mathrm{kg} \mathrm{ha}{ }^{-1}$. The recommended dose of fertilizers $\left(150 \mathrm{~N}, 75 \mathrm{P}_{2} \mathrm{O}_{5}\right.$ and $37.5 \mathrm{~K}_{2} \mathrm{O} \mathrm{kg}$ $\mathrm{ha}^{-1}$ ) was given to the crop and the standard agronomic practices were followed to raise a healthy crop.

Following data collections, the data obtained on various characters were subjected to analysis by applying standard statistical techniques. Analysis of variance (ANOVA) for individual characters was carried out on the basis of mean value per entry per replication as suggested by Panse and Sukhatme (1967) for randomized block design (RBD). The coefficient of variability both at phenotypic and genotypic levels for all the characters were computed by applying the formula suggested by Burton and De Vane (1953). Heritability $\left(\mathrm{h}^{2}\right.$ bs $)$ in the broad sense was calculated according to the formulae given by Hanson et al., (1953). From the heritability estimates, the genetic advance was estimated by the following formulae as given by Johnson et al., (1955). Genetic advance as per cent of mean was calculated by using the formulae given by Johnson et al., (1955). Correlation was computed by using the formulae given by Singh and Narayanan (1993). Path coefficient analysis was performed as given by Wright (1921) and Dewey and Lu (1959).

\section{Results and Discussion}

\section{Genetic variability}

In crop breeding variability plays an important role. The analysis of variance was carried out to partition the total variance into variance due to genotype and other sources for all characters. The results of analysis of variance for 15 characters in maize inbred lines revealed that mean sum of square due to inbred lines were significant for 14 characters 
viz., cob length, cob girth, number of grain rows, number of grains per row, number of grains per cob, plant height, number of leaves, number of internodes, grain yield per plant, 1000-kernel weight, shelling percentage, days to $50 \%$ anthesis, days to $50 \%$ silking and grain yield ( $\mathrm{kg} / \mathrm{ha}$ ) and non significant for anthesis silking interval and are presented in Table 1.

\section{Phenotypic and genotypic coefficient of} variation

Genotypic and Phenotypic coefficient of variability, heritability, genetic advance and genetic advance as percent of mean estimates are presented in Table 2. It was apparent that there existed almost perfect relation between phenotypic coefficient of variation (PCV) and genotypic coefficient of variation (GCV). The magnitude of PCV was higher compared to GCV for all the characters. High GCV and PCV was observed for number of grains per $\mathrm{cob}$, grain yield per plant, grain yield (kg/ha). Moderate GCV and PCV were observed for number of grains per row, plant height, 1000 kernel weight and anthesis silking interval. Low GCV and PCV was observed for days to $50 \%$ anthesis, days to $50 \%$ silking, number of leaves per plant.

\section{Heritability and genetic advance}

Characters like number of grains per row, number of grains per cob, plant height, grain yield per plant, 1000 kernel weight, shelling percentage, days to $50 \%$ anthesis, days to $50 \%$ silking and grain yield $\mathrm{kg} / \mathrm{ha}$ exhibited high heritability which indicating that selection of these characters were useful for further generation in improvement of breeding programme. Moderate estimates of heritability were observed for cob length, cob girth, number of grain rows. Low estimates of heritability were observed for number of leaves and number of internodes. The high estimates of genetic advance ( $\%$ of mean) were observed for number of grains per row, number of grains per cob, plant height, grain yield per plant, 1000 kernel weight and grain yield $\mathrm{kg} / \mathrm{ha}$. The moderate estimates of genetic advance (\% of mean) were observed for cob length, cob girth and number of grain rows, while lower genetic advance (\% of mean) were observed for number of leaves, number of internodes, shelling percentage, days to $50 \%$ anthesis and days to $50 \%$ silking.

The high heritability coupled with high genetic advance ( $\%$ of mean) were observed for number of grains per row, number of grains per cob, plant height, grain yield per plant, 1000 kernel weight and grain yield $\mathrm{kg} / \mathrm{ha}$. The high heritability associated with low genetic advance (\% of mean) was observed for shelling percentage, days to $50 \%$ anthesis and days to $50 \%$ silking. Whereas moderate heritability coupled with moderate genetic advance ( $\%$ of mean) was observed for cob length, cob girth and number of grain rows. The low heritability associated with low genetic advance (\% of mean) was observed for number of leaves and number of internodes.

\section{Character association}

Studies on correlation coefficients of different plant traits are useful criterion to identify desirable traits that contribute to improve the dependent variable (grain yield).

The genotypic and phenotypic correlations among the traits studied pointed out the existence of several statistically significant relationships and are presented in Table 3.

The important yield attributing traits viz. shelling percentage, number of grains per row and plant height showed positive association at both phenotypic and genotypic levels.

Whereas, grain yield recorded significant positive association with number of leaves, 
number of internodes, cob length and number of grains per cob whereas significant negative correlation with days to $50 \%$ anthesis, days to $50 \%$ silking, ASI and number of grain rows only at genotypic level.

\section{Path coefficient analysis}

Correlation is not sufficient to explain the true association as it does not indicate the cause and effect relationship, hence the correlated traits have to be further analysed for their direct effects of specific yield components on yield and also indirect effects via other yield components on grain yield. The results of path coefficient analysis and the direct and indirect effects of each coefficient are given in Table 4 and Table 5. Grain yield per plant as dependent variable was evaluated against other measured traits as independent variables. Path analysis revealed that most of the traits had positive direct effect on grain yield.

At phenotypic level, the character number of grains per cob recorded highest positive direct effect on grain yield followed by shelling percentage, days to $50 \%$ anthesis and plant height.

High indirect positive effect on grain yield was exhibited by number of grains per cob through plant height, number of leaves, number of internodes, cob length, cob girth, number of grain rows and number of grains per row.

At genotypic level, the characters viz. days to $50 \%$ anthesis, number of grains per cob, shelling percentage exhibited high direct positive effect on grain yield. The indirect high positive effect on grain yield was exhibited by days to $50 \%$ anthesis through days to $50 \%$ silking; number of grains per cob via plant height, number of leaves, number of internodes, cob length, cob girth, number of grain rows and number of grains per row.
Phenotypic and genotypic coefficient of variation

Reddy et al., (2012) evaluated high GCV and PCV estimates for grain yield per plant, ear girth. Bharathiveeramani et al., (2012b) reported low GCV and PCV estimates for days to $50 \%$ tasseling, days to $50 \%$ silking and number of leaves per plant. On the contrary, Langade et al., (2013) evaluated highest phenotypic and genotypic coefficients of variation for days to $50 \%$ tasseling and days to $50 \%$ silking. GCV was less than its corresponding estimates of PCV which indicated significant role of environment in the expression of trait.

\section{Heritability and genetic advance}

Sumathi et al., (2005) reported high estimates of heritability coupled with high genetic advance as per cent of mean for plant height, total number of kernels per ear, grain yield while, high heritability with low genetic advance as per cent of mean was observed for days to $50 \%$ tasseling and days to $50 \%$ silking. High heritability estimates indicating the preponderance of additive gene action.

This trait was predominantly under the control of additive gene action and hence, the character can be improved by selection.

\section{Character association}

The important yield attributing traits viz., shelling percentage, number of grains per row and plant height showed positive association at both phenotypic and genotypic levels.

Hence, selection for any of these traits would result in the improvement of grain yield. Wali et al., (2006) and Hefny et al., (2011) reported significant positive association of grain yield with plant height and cob length at both phenotypic and genotypic levels. 
Table.1 Analysis of variance for 15 characters in maize inbred lines

\begin{tabular}{|c|c|c|c|c|c|c|c|c|c|c|c|c|c|c|c|c|}
\hline $\begin{array}{c}\text { Source } \\
\text { of } \\
\text { variation }\end{array}$ & Df & DFA & DFS & ASI & PH & NL & NI & CL & CG & NGR & NGPR & NGPC & SP & TKW & GYP & GY(kg/ha) \\
\hline $\begin{array}{l}\text { Replicati } \\
\text { on }\end{array}$ & 2 & 3.40 & 1.01 & 0.75 & 831.13 & 3.56 & 0.39 & 25.94 & 16.08 & 5.71 & 18.61 & 15990.84 & 1.00 & 1960.16 & 12.69 & 728488.30 \\
\hline $\begin{array}{c}\text { Treatme } \\
\text { nts }\end{array}$ & 49 & $\begin{array}{c}35.18 \\
* *\end{array}$ & $\begin{array}{c}32.60 \\
* *\end{array}$ & 0.45 & $\begin{array}{c}1725.80 \\
* *\end{array}$ & $\begin{array}{l}2.57 \\
* *\end{array}$ & $\begin{array}{r}2.43 \\
* *\end{array}$ & $\begin{array}{c}6.79 \\
* *\end{array}$ & $\begin{array}{c}3.69 \\
* *\end{array}$ & $\begin{array}{c}4.68 \\
* *\end{array}$ & $63.12 * *$ & $\begin{array}{c}19845.70 * \\
*\end{array}$ & $\begin{array}{c}42.17 \\
* *\end{array}$ & $\begin{array}{c}7987.71 * \\
*\end{array}$ & $\begin{array}{c}97.92 \\
* *\end{array}$ & $\begin{array}{c}4405907.58 * \\
*\end{array}$ \\
\hline Error & 98 & 5.08 & 5.18 & 0.78 & 124.02 & 1.24 & 1.18 & 1.91 & 0.98 & 0.85 & 4.09 & 1520.21 & 3.69 & 487.20 & 7.07 & 114179.38 \\
\hline
\end{tabular}

** Significant at $1 \%$ level $(\mathbf{P}=\mathbf{0 . 0 1})$

DFA- Days to 50\% anthesis, DFS- Days to 50\% silking, ASI- Anthesis silking interval, PH- Plant height, NL- Number of leaves, NI- Number of internodes, CL- Cob length, CG- Cob girth, NGR- Number of grain rows per cob, NGPR- Number of grains per row, NGPC- Number of grains per cob, SP- Shelling percentage, TKW- 1000 kernel weight, GYP- grain yield per plant, GY(kg/ha)- Grain yield (kg/ha) 
Table.2 Estimation of genetic variability parameters among inbred lines for yield and its related traits in 50 maize (Zea mays L.) inbred lines

\begin{tabular}{|c|c|c|c|c|c|c|c|c|c|}
\hline Sl.N & \multirow[t]{2}{*}{ Character } & \multirow[t]{2}{*}{ Mean } & \multicolumn{2}{|c|}{ Range } & \multicolumn{2}{|c|}{ Coefficient variation } & \multirow[t]{2}{*}{$h^{2}(\%)$} & \multirow[t]{2}{*}{ GA } & \multirow[t]{2}{*}{ GAM (\%) } \\
\hline o. & & & Minimum & Maximum & $\operatorname{PCV}(\%)$ & GCV (\%) & & & \\
\hline 1 & Days to $50 \%$ anthesis & 61.73 & 55.66 & 67.33 & 6.29 & 5.13 & 66.4 & 5.31 & 8.61 \\
\hline 2 & Days to $50 \%$ silking & 63.57 & 57.00 & 69.33 & 5.95 & 4.75 & 63.8 & 4.97 & 7.82 \\
\hline 3 & Anthesis silking interval & 1.84 & 1.10 & 2.66 & 44.63 & 18.03 & 16.3 & 0.27 & 15.00 \\
\hline 4 & Plant height & 157.71 & 94.00 & 206.33 & 16.26 & 14.65 & 81.2 & 42.88 & 27.18 \\
\hline 5 & Number of leaves & 12.40 & 10.06 & 14.26 & 10.47 & 5.38 & 26.4 & 0.70 & 5.70 \\
\hline 6 & Number of internodes & 12.38 & 10.46 & 14.60 & 10.21 & 5.21 & 26.1 & 0.68 & 5.48 \\
\hline 7 & Cob length & 14.17 & 10.76 & 17.16 & 13.28 & 8.99 & 45.8 & 1.77 & 12.53 \\
\hline 8 & Cob girth & 13.28 & 11.10 & 15.20 & 10.35 & 7.15 & 47.7 & 1.35 & 10.17 \\
\hline 9 & Number of grain rows & 14.03 & 12.00 & 16.80 & 10.40 & 8.04 & 59.7 & 1.79 & 12.81 \\
\hline 10 & Number of grains per row & 27.20 & 16.53 & 38.06 & 17.92 & 16.30 & 82.8 & 8.31 & 30.56 \\
\hline 11 & Number of grains per cob & 383.88 & 207.50 & 563.56 & 22.75 & 20.35 & 80.1 & 144.07 & 37.53 \\
\hline 12 & Shelling percentage & 79.49 & 72.33 & 85.66 & 5.11 & 4.50 & 77.6 & 6.49 & 8.17 \\
\hline 13 & 1000 kernel weight & 254.36 & 151.66 & 361.66 & 21.48 & 19.65 & 83.7 & 94.23 & 37.04 \\
\hline 14 & Grain yield/plant & 21.44 & 11.90 & 38.03 & 28.49 & 25.65 & 81.1 & 10.20 & 47.58 \\
\hline 15 & Grain yield (kg/ha) & 4187.37 & 1312.70 & 7698.56 & 29.68 & 28.56 & 92.6 & 2371.09 & 56.62 \\
\hline
\end{tabular}


Table.3 Phenotypic and genotypic correlation among yield and its attributing traits in 50 maize (Zea mays L.) inbred lines

\begin{tabular}{|c|c|c|c|c|c|c|c|c|c|c|c|c|c|c|c|}
\hline Character & & DFA & DFS & ASI & PH & NL & NI & CL & CG & NGR & NGPR & NGPC & SP & TKW & GYP \\
\hline \multirow[t]{2}{*}{ DFA } & $\mathrm{P}$ & 1.000 & $0.977^{* * *}$ & $-0.229 * *$ & -0.138 & 0.033 & 0.120 & -0.053 & $-0.178^{*}$ & $-0.188^{*}$ & $-0.202^{*}$ & $-0.252 * *$ & -0.149 & -0.001 & -0.128 \\
\hline & G & 1.000 & $0.981 * *$ & $0.371^{* *}$ & -0.101 & 0.136 & $0.329^{* * *}$ & -0.043 & $-0.261 * *$ & $-0.359 * *$ & $-0.297 * *$ & $-0.387 * *$ & $-0.193^{*}$ & 0.059 & $-0.216^{* *}$ \\
\hline \multirow[t]{2}{*}{ DFS } & $\mathrm{P}$ & & 1.000 & -0.018 & -0.111 & 0.054 & 0.142 & -0.039 & -0.135 & $-0.185^{*}$ & $-0.177 *$ & $-0.230 * *$ & -0.150 & -0.006 & -0.130 \\
\hline & G & & 1.000 & 0.499 ** & -0.083 & 0.158 & $0.350^{* *}$ & -0.009 & $-0.252 * *$ & $-0.324 * *$ & $-0.256^{* *}$ & $-0.340 * *$ & $-0.205^{*}$ & 0.067 & $-0.198^{*}$ \\
\hline \multirow[t]{2}{*}{ ASI } & $\mathrm{P}$ & & & 1.000 & 0.142 & 0.094 & 0.086 & 0.068 & $0.222 * *$ & 0.041 & 0.139 & 0.134 & 0.015 & -0.024 & 0.009 \\
\hline & G & & & 1.000 & $-0.207^{*}$ & -0.143 & -0.044 & $-0.321 * *$ & $-0.194 *$ & $-0.466^{* *}$ & $-0.500 * *$ & $-0.596 * *$ & 0.027 & -0.052 & $-0.258 * *$ \\
\hline \multirow[t]{2}{*}{ PH } & $\mathrm{P}$ & & & & 1.000 & $0.567^{* * *}$ & $0.534 * *$ & $0.425 * *$ & $0.587 * *$ & $0.321 * *$ & $0.586^{* *}$ & $0.590^{* * *}$ & 0.145 & $0.217 * *$ & $0.161^{*}$ \\
\hline & G & & & & 1.000 & $0.894 * *$ & $0.845 * *$ & $0.559 * *$ & $0.680 * *$ & $0.392 * *$ & $0.687 * *$ & $0.679 * *$ & 0.137 & $0.231 * *$ & $0.219 * *$ \\
\hline \multirow[t]{2}{*}{ NL } & $\mathrm{P}$ & & & & & 1.000 & $0.781 * *$ & $0.343^{* *}$ & $0.422 * *$ & $0.166^{*}$ & $0.400 * *$ & $0.381 * *$ & 0.107 & $0.239 * *$ & 0.094 \\
\hline & G & & & & & 1.000 & $0.850 * *$ & $0.488 * *$ & $0.608^{* *}$ & $0.351 * *$ & $0.768 * *$ & $0.739 * *$ & $0.177 *$ & $0.329 * *$ & $0.268 * *$ \\
\hline \multirow[t]{2}{*}{ NI } & $\mathrm{P}$ & & & & & & 1.000 & $0.256^{* *}$ & $0.352 * *$ & 0.135 & $0.389 * *$ & $0.353^{* *}$ & 0.057 & $0.199 *$ & 0.079 \\
\hline & G & & & & & & 1.000 & $0.351 * *$ & $0.560 * *$ & $0.200 *$ & $0.765 * *$ & $0.673 * *$ & 0.033 & $0.269 * *$ & $0.252^{* *}$ \\
\hline \multirow[t]{2}{*}{ CL } & $P$ & & & & & & & 1.000 & $0.555^{* *}$ & $0.175^{*}$ & $0.560 * *$ & $0.515^{* * *}$ & 0.122 & $0.334 * *$ & 0.151 \\
\hline & G & & & & & & & 1.000 & $0.598 * *$ & 0.125 & $0.774 * *$ & $0.658 * *$ & 0.145 & $0.364 * *$ & $0.248 * *$ \\
\hline \multirow[t]{2}{*}{ CG } & $\mathrm{P}$ & & & & & & & & 1.000 & $0.483 * *$ & $0.503 * *$ & $0.598 * *$ & $0.190 *$ & $0.275 * *$ & 0.031 \\
\hline & G & & & & & & & & 1.000 & $0.687 * *$ & $0.733 * *$ & $0.825 * *$ & $0.219 * *$ & $0.409 * *$ & 0.065 \\
\hline \multirow[t]{2}{*}{ NGR } & $P$ & & & & & & & & & 1.000 & $0.291 * *$ & $0.667 * *$ & 0.059 & 0.020 & -0.096 \\
\hline & G & & & & & & & & & 1.000 & $0.377 * *$ & $0.678^{* * *}$ & 0.052 & -0.020 & $-0.170^{*}$ \\
\hline \multirow[t]{2}{*}{ NGPR } & $\mathrm{P}$ & & & & & & & & & & 1.000 & $0.902 * *$ & $0.177^{*}$ & $0.175^{*}$ & 0.231 ** \\
\hline & G & & & & & & & & & & 1.000 & $0.934 * *$ & $0.234 * *$ & $0.208^{*}$ & $0.323^{* * *}$ \\
\hline \multirow[t]{2}{*}{ NGPC } & $\mathrm{P}$ & & & & & & & & & & & 1.000 & $0.176^{*}$ & 0.146 & 0.148 \\
\hline & G & & & & & & & & & & & 1.000 & $0.222 * *$ & 0.157 & $0.203^{*}$ \\
\hline \multirow[t]{2}{*}{ SP } & $\mathrm{P}$ & & & & & & & & & & & & 1.000 & $0.220 * *$ & $0.466^{* * *}$ \\
\hline & G & & & & & & & & & & & & 1.000 & $0.279 * *$ & $0.538 * *$ \\
\hline \multirow[t]{2}{*}{ TKW } & $\mathrm{P}$ & & & & & & & & & & & & & 1.000 & 0.115 \\
\hline & G & & & & & & & & & & & & & 1.000 & 0.144 \\
\hline \multirow[t]{2}{*}{ GYP } & $P$ & & & & & & & & & & & & & & 1.000 \\
\hline & G & & & & & & & & & & & & & & 1.000 \\
\hline
\end{tabular}

$3 * *$ Significant at $1 \%$ level $(P=0.01)$

* Significant at $5 \%$ level $(P=0.05)$

DFA- Days to 50\% anthesis, DFS- Days to 50\% silking, ASI- Anthesis silking interval, PH- Plant height, NL- Number of leaves, NI- Number of internodes, CL- Cob length, CG- Cob girth, NGR- Number of grain rows per cob, NGPR- Number of grains per row, NGPC- Number of grains per cob, SP- Shelling percentage, TKW- 1000 kernel weight, GYP- grain yield per plant 
Table.4 Phenotypic path analysis of yield and its attributing traits in 50 maize (Zea mays L.) inbred lines

\begin{tabular}{|c|c|c|c|c|c|c|c|c|c|c|c|c|c|c|}
\hline & DFA & DFS & ASI & PH & NL & NI & CL & CG & NGR & NGPR & NGPC & SP & TKW & $\begin{array}{c}\text { 'r' with } \\
\text { GYP }\end{array}$ \\
\hline DFA & 0.235 & 0.229 & -0.054 & -0.032 & 0.007 & 0.028 & -0.012 & -0.042 & -0.044 & -0.047 & -0.059 & -0.035 & -0.000 & -0.128 \\
\hline DFS & -0.284 & -0.291 & 0.005 & 0.032 & -0.015 & -0.041 & 0.011 & 0.039 & 0.053 & 0.051 & 0.067 & 0.043 & 0.001 & -0.130 \\
\hline ASI & -0.009 & -0.000 & 0.042 & 0.006 & 0.004 & 0.003 & 0.002 & 0.009 & 0.001 & 0.005 & 0.005 & 0.000 & -0.001 & 0.009 \\
\hline $\mathbf{P H}$ & -0.016 & -0.013 & 0.017 & 0.119 & 0.067 & 0.063 & 0.050 & 0.070 & 0.038 & 0.070 & 0.070 & 0.017 & 0.026 & $0.161 *$ \\
\hline NL & -0.000 & -0.001 & -0.002 & -0.015 & -0.027 & -0.021 & -0.009 & -0.011 & -0.004 & -0.011 & -0.010 & -0.003 & -0.006 & 0.094 \\
\hline NI & 0.003 & 0.004 & 0.002 & 0.015 & 0.022 & 0.028 & 0.007 & 0.010 & 0.003 & 0.011 & 0.010 & 0.001 & 0.005 & 0.079 \\
\hline CL & -0.004 & -0.003 & 0.005 & 0.033 & 0.026 & 0.020 & 0.077 & 0.043 & 0.013 & 0.043 & 0.040 & 0.009 & 0.026 & 0.151 \\
\hline CG & 0.030 & 0.023 & -0.038 & -0.101 & -0.072 & -0.060 & -0.095 & -0.172 & -0.083 & -0.086 & -0.103 & -0.032 & -0.047 & 0.031 \\
\hline NGR & 0.107 & 0.105 & -0.023 & -0.183 & -0.095 & -0.077 & -0.100 & -0.276 & -0.570 & -0.166 & -0.380 & -0.033 & -0.011 & -0.096 \\
\hline NGPR & 0.116 & 0.102 & -0.080 & -0.338 & -0.230 & -0.224 & -0.323 & -0.290 & -0.167 & -0.576 & -0.520 & -0.102 & -0.101 & $0.231 * *$ \\
\hline NGPC & -0.241 & -0.219 & 0.128 & 0.563 & 0.363 & 0.337 & 0.492 & 0.571 & 0.637 & 0.861 & 0.954 & 0.168 & 0.140 & 0.148 \\
\hline SP & -0.065 & -0.065 & 0.006 & 0.063 & 0.046 & 0.025 & 0.053 & 0.082 & 0.025 & 0.077 & 0.076 & 0.435 & 0.095 & $0.466 * *$ \\
\hline TKW & 0.000 & 0.000 & 0.000 & -0.002 & -0.002 & -0.002 & -0.003 & -0.003 & -0.000 & -0.002 & -0.001 & -0.002 & -0.011 & 0.115 \\
\hline
\end{tabular}

** Significant at $1 \%$ level $(\mathbf{P}=\mathbf{0 . 0 1})$

* Significant at $5 \%$ level $(P=0.05)$

DFA- Days to 50\% anthesis, DFS- Days to 50\% silking, ASI- Anthesis silking interval, PH- Plant height, NL- Number of leaves, NI- Number of internodes, CL- Cob length, CG- Cob girth, NGR- Number of grain rows per cob, NGPR- Number of grains per row, NGPC- Number of grains per cob, SP- Shelling percentage, TKW- 1000 kernel weight, GYP-grain yield per plant, r- Correlation coefficient 
Table.5 Genotypic path analysis of yield, yield attributing traits in 50 maize (Zea mays L.) inbred lines

\begin{tabular}{|c|c|c|c|c|c|c|c|c|c|c|c|c|c|c|}
\hline & DFA & DFS & ASI & PH & NL & NI & CL & CG & NGR & NGPR & NGPC & SP & TKW & $\begin{array}{c}\text { 'r' with } \\
\text { GYP }\end{array}$ \\
\hline DFA & 0.7570 & 0.762 & 0.281 & -0.077 & 0.103 & 0.249 & -0.032 & -0.197 & -0.271 & -0.224 & -0.293 & -0.146 & 0.044 & $-0.216 * *$ \\
\hline DFS & -0.846 & -0.840 & -0.419 & 0.070 & -0.133 & -0.294 & 0.008 & 0.212 & 0.273 & 0.215 & 0.285 & 0.173 & -0.056 & $-0.198 *$ \\
\hline ASI & 0.000 & 0.000 & 0.000 & 0.000 & 0.000 & 0.000 & 0.000 & 0.000 & 0.000 & 0.000 & 0.000 & 0.000 & 0.000 & $-0.258 * *$ \\
\hline PH & -0.022 & -0.018 & -0.046 & 0.223 & 0.200 & 0.189 & 0.125 & 0.152 & 0.087 & 0.153 & 0.152 & 0.030 & 0.051 & $0.219 * *$ \\
\hline NL & 0.015 & 0.018 & -0.016 & 0.101 & 0.113 & 0.119 & 0.055 & 0.069 & 0.039 & 0.087 & 0.084 & 0.020 & 0.037 & $0.268 * *$ \\
\hline NI & -0.053 & -0.057 & 0.007 & -0.138 & -0.171 & -0.163 & -0.057 & -0.091 & -0.032 & -0.125 & -0.110 & -0.005 & -0.044 & $0.252 * *$ \\
\hline CL & 0.004 & 0.001 & 0.033 & -0.058 & -0.050 & -0.036 & -0.104 & -0.062 & -0.013 & -0.080 & -0.068 & -0.015 & -0.038 & $0.248 * *$ \\
\hline CG & 0.094 & 0.091 & 0.070 & -0.245 & -0.219 & -0.202 & -0.216 & -0.360 & -0.248 & -0.264 & -0.297 & -0.079 & -0.147 & 0.065 \\
\hline NGR & 0.167 & 0.151 & 0.217 & -0.182 & -0.163 & -0.093 & -0.058 & -0.320 & -0.465 & -0.175 & -0.316 & -0.024 & 0.009 & $-0.170 *$ \\
\hline NGPR & -0.013 & -0.011 & -0.022 & 0.030 & 0.033 & 0.033 & 0.034 & 0.032 & 0.016 & 0.044 & 0.041 & 0.010 & 0.009 & $0.323 * *$ \\
\hline NGPC & -0.241 & -0.211 & -0.371 & 0.423 & 0.460 & 0.419 & 0.410 & 0.514 & 0.422 & 0.581 & 0.622 & 0.138 & 0.097 & $0.203^{*}$ \\
\hline SP & -0.081 & -0.086 & 0.011 & 0.057 & 0.074 & 0.014 & 0.061 & 0.092 & 0.022 & 0.098 & 0.093 & 0.419 & 0.117 & $0.538 * *$ \\
\hline TKW & 0.003 & 0.004 & -0.003 & 0.014 & 0.021 & 0.017 & 0.023 & 0.026 & -0.001 & 0.013 & 0.010 & 0.017 & 0.063 & 0.144 \\
\hline
\end{tabular}

** Significant at $1 \%$ level $(P=0.01)$

* Significant at $5 \%$ level $(P=\mathbf{0 . 0 5})$

DFA- Days to 50\% anthesis, DFS- Days to 50\% silking, ASI- Anthesis silking interval, PH- Plant height, NL- Number of leaves, NI- Number of internodes, CL- Cob length, CG- Cob girth, NGR- Number of grain rows per cob, NGPR- Number of grains per row, NGPC- Number of grains per cob, SP- Shelling percentage, TKW- 1000 kernel weight, GYP-grain yield per plant, GY(kg/ha)- Grain yield (kg/ha) 


\section{Path coefficient analysis}

Path coefficient analysis revealed that grain yield was primarily influenced by number of grains per cob and days to $50 \%$ anthesis at phenotypic and genotypic levels respectively, which showed maximum direct effect on grain yield per plant. Hence, it may be considered as a selection criterion. Raghu et al., (2011) and Lingaiah et al., (2014) reported that selected traits showed direct and indirect effects on grain yield.

This study concluded that the variations observed for the 50 traits attributed to diverse genetic background of the inbred lines studied. According to Alake et al., (2008) in a population of maize genotypes, there is an opportunity to select desirable genotypes with increased yield components traits which may be able to perform well and give increased yield. Due to highly positive direct effect on grain yield and also indirect effect via all other traits could provide a good selection criteria for high yielding maize lines. Hence, selection for these traits will increase the grain yield of maize.

\section{References}

Alake, C. O., Ojo, D. K., Oduwaye, O. A. and Adekoya, M. A., 2008. Genetic variability and correlation studies in yield and yield related characters of tropical maize (Zea Mays L.). Asset Series A, 8 (1): 14-27.

Bharathiveeramani, B., Prakash, M. and Seetaram, A., 2012b. Variability studies of quantitative characters in maize (Zea mays L.). Electron. J. Plant Breed., 3(4): 995-997.

Burton, G.W., 1952, De Vane, 1953. Estimating heritability in tall Fescue from replicated clonal material. Agron. J., 45(3): 474-481.

Dewey, D. R. and Lu, K. H., 1959. A correlation and path coefficient analysis of components of crested wheat grass seed production. Agron. J., 51(9): 515-518.

Ghosh, A., Subba, V., Roy, A., Ghosh, A. and Kundagrami, S., 2014. Genetic variability and character association of grain yield components in some inbred lines of maize (Zea mays L.). Journal of Argo ecology and Natural Resource Management, 1(2), pp.34-39.

Hanson, G. H., Robinson, H. F. and Comstack, R. E., 1953. Biometrical studies of yield in segregating populations of Korean Lespedeza. Agron. J., 48: 267-282.

Hefny, M., 2011. Genetic parameters and path analysis of yield and its components in corn inbred lines (Zea mays L.) at different sowing dates. Asian J. Crop Sci., 3(3): 106-117.

Johnson, H. W., Robinson, H. and Comstock, R. F., 1955. Estimates of genetic and environmental variability in soybean. Agron. J., 47: 314-318.

Langade, D. M., Shahi, J. P., Srivastava, K., Singh, A., Agarwal, V. K. and Sharma, A., 2013. Appraisal of genetic variability and seasonal interaction for yield and quality traits in maize (Zea mays L.). Plant Gene and Trait, 4 (18): 95-103.

Lingaiah, N., Kumar, G. P. and Venkanna, V., 2014. Character association and path analysis for yield contributing and physiological parameters for grain yield in maize (Zea mays L.). Int. J. Pure Appl. Biosci., 2 (1): 118-121.

Panse, V. G. and Sukhatme, P. V., 1967. Statistical methods for agricultural workers. ICAR, New Delhi.

Raghu, B., Suresh, J., Kumar, S. S and Saidaiah, P., 2011. Character association and path analysis in maize (Zea mays L.). Madras Agric. J., 98(13): 7-9. 
Reddy, V. R., Jabeen, F., Sudarshan, M. R. and Rao, A. S., 2012. Studies on genetic variability, heritability, correlation and path analysis in maize (Zea mays L.) over locations. Int. J. Appl. Biol. and Pharm., 4 (1): 195199.

Singh, P. and Narayanan, S. S., 1993. Biometrial techniques in plant breeding. Kalyani Publishers, New Delhi.

Sumathi, P., Nirmalakumari, A. and Mohanraj, K., 2005. Genetic variability and traits interrelationship studies in industrially utilized oil rich CIMMYT lines of maize (Zea mays L.). Madras Agric. J., 92(10-12): 612617.

Wali, M. C., Salimath, P. M., Prashanth, M. and Harlapur, S. I., 2006. Studies on character association as influenced by yield, starch and oil in maize (Zea mays L.). Karnataka J. Agric. Sci., 19(4): 932-935.

Wright, S., 1921. Correlation and causation. $J$. Agric. Res., 20: 557-580.

\section{How to cite this article:}

Supraja, V., H. C. Sowmya, P. H. Kuchanur, B. Arunkumar and Kisan, B. 2019. Genetic Variability and Character Association Studies in Maize (Zea mays L.) Inbred Lines. Int.J.Curr.Microbiol.App.Sci. 8(10): 646-656. doi: https://doi.org/10.20546/ijcmas.2019.810.073 